\title{
Pengaruh Lactobacillus reuteri DSM 17938 Terhadap Kadar Calprotectin Feses sebagai Penanda Inflamasi Intestinal pada Bayi Kurang Bulan
}

Tisa Rahmawaty Savitri, Sjarif Hidajat, Anggraini Alam

Departemen Ilmu Kesehatan Anak Fakultas Kedokteran Universitas Padjadjaran/RSUP Dr Hasan Sadikin, Bandung

Latar belakang. Bayi kurang bulan (BKB) berisiko mengalami inflamasi intestinal akibat imaturitas fungsi saluran cerna. Penelitian terdahulu melaporkan pro-kontra probiotik yang dapat menurunkan kejadian penyakit inflamasi intestinal pada BKB, seperti enterokolitis nekrotikans dan sepsis. Pengukuran calprotectin feses sebagai penanda penyakit inflamasi merupakan metode noninvasif, cepat, dan mudah dilakukan.

Tujuan. Mengetahui pengaruh Lactobacillus reuteri DSM 17938 terhadap kadar calprotectin feses pada BKB.

Metode. Penelitian eksperimental acak terkontrol pada BKB yang lahir di Rumah Sakit Dr. Hasan Sadikin Bandung selama bulan Maret sampai Juni 2018. Kelompok probiotik diberikan Lactobacillus reuteri DSM 17938 selama 14 hari dan kelompok kontrol diberikan plasebo. Kadar calprotectin feses diperiksa sebelum dan sesudah perlakuan. Calprotectin diperiksakan menggunakan metode enzymed-linked immunosorbent assay (ELISA). Data dianalisis menggunakan uji Mann-Whitney dan Wilcoxon Signed Rank, tingkat kemaknaan hasil uji ditentukan berdasarkan nilai $\mathrm{p}<0,05$.

Hasil. Empat puluh bayi diikutsertakan, 4 di antaranya mengalami dropout. Tiga puluh enam bayi yang dianalisis terbagi menjadi kelompok probiotik $(\mathrm{n}=18)$ dan nonprobiotik $(\mathrm{n}=18)$. Karakteristik dasar tidak berbeda antara kedua kelompok. Sebelum perlakuan, kadar calprotectin feses kedua kelompok tidak berbeda secara signifikan ( $\mathrm{p}=0,88)$. Kadar calprotectin feses kelompok probiotik lebih rendah secara signifikan dibandingkan dengan kelompok nonprobiotik setelah perlakuan $(\mathrm{p}<0,001)$.

Kesimpulan. Pemberian Lactobacillus reuteri DSM 17938 dapat menurunkan kadar calprotectin feses. Sari Pediatri 2018;20(3):171-77

Kata kunci: bayi kurang bulan, calprotectin, probiotik

\section{The Effect of Lactobacillus reuteri DSM 17938 on Fecal Calprotectin as A Marker of Intestinal Inflammation in Preterm Infant}

Tisa Rahmawaty Savitri, Sjarif Hidajat, Anggraini Alam

Background. Preterm infants have risks to suffer intestinal inflammation due to immature function of the gastrointestinal tract. Previous studies reported procons probiotic could reduce the incidence of intestinal inflammatory disease in preterm infants such as necrotizing enterocolitis and sepsis. Fecal calprotectin measurement as a marker of inflammatory disease is a noninvasive, fast and simple method.

Objective. To determine the effect of Lactobacillus reuteri DSM 17938 on fecal calprotectin in preterm infants.

Methods. A randomized controlled trial of newborn preterm infants was conducted in Dr. Hasan Sadikin Hospital Bandung during March to June 2018. The probiotic group was given Lactobacillus reuteri DSM 17938 for 14 days and the control group was given placebo. Fecal calprotectin was determined by an enzyme-linked immunosorbent assay (ELISA) before and after intervention. We used Mann-Whitney and Wilcoxon Signed Rank test analysis with a significance level of $\mathrm{p}<0.05$.

Results. Forty preterm infants were enrolled, 4 of which were dropped out. The rest 36 preterm infants were divided into probiotics $(\mathrm{n}=18)$ and nonprobiotics $(\mathrm{n}=18)$. The basic characteristics of both groups were similar. At pre-intervention, the fecal calprotectin did not differ significantly between probiotics and nonprobiotics group $(\mathrm{p}=0,88)$. In the probiotic group, the fecal calprotectin was significantly lower than nonprobiotic group post-intervention $(\mathrm{p}<0.001)$.

Conclusion. Lactobacillus reuteri DSM 17938 administration might decrease the fecal calprotectin level. Sari Pediatri 2018;20(3):171-77

Keywords: preterm infants, calprotectin, probiotic

Alamat korespondensi: Tisa Rahmawaty Savitri. Departemen Ilmu Kesehatan Anak Fakultas Kedokteran Universitas Padjadjaran, RSUP Dr Hasan Sadikin Bandung, Indonesia. JL. Pasteur no 38 Bandung 40151. E-mail: tisa_rahmawaty@yahoo.com 
$\mathrm{K}$ elahiran kurang bulan bertanggung jawab terhadap 35\% kematian bayi di dunia. ${ }^{1}$ Tahun 2017 angka kematian bayi di end hidup. Prematuritas, infeksi, dan asfiksia merupakan tiga penyebab terbanyak kematian bayi di Indonesia. Bayi kurang bulan (BKB) lebih rentan mengalami sepsis dibandingkan bayi cukup bulan (BCB). Penelitian menunjukkan bahwa BKB memiliki risiko 4,8 kali untuk mengalami sepsis dibandingkan BCB. ${ }^{2}$ Bayi kurang bulan memiliki sistem fisiologis imatur akibat fungsi gastrointestinal yang belum matang. Imaturitas fungsi pencernaan pada BKB seperti kemampuan motilitas, digesti, regulasi sirkulasi, fungsi pertahanan intestinal dan imaturitas sistem imunitas saluran cerna menyebabkan BKB berisiko tinggi mengalami enterokolitis nekrotikans (EKN) dan sepsis. ${ }^{3,4}$

Bukti saat ini menunjukkan bahwa suplementasi probiotik secara signifikan mengurangi semua penyebab mortalitas dan morbiditas pada neonatus. Penggunaan probiotik di bidang neonatologi telah banyak direkomendasikan karena manfaat yang didapat terutama pada bayi yang lahir secara seksio sesarea, bayi yang tidak mendapat air susu ibu (ASI), dan BKB. ${ }^{5}$

Probiotik dapat mencegah terjadinya EKN melalui peranannya sebagai barrier migrasi bakteri melintasi mukosa intestinal, kompetitor flora patogen, mengurangi permeabilitas intestinal, menciptakan keseimbangan mikrobiota, efek proteksi mukosa terhadap kolonisasi patogen dan meningkatkan sitokin antiinflamasi. ${ }^{6-8}$

Pada beberapa penelitian telah menyebutkan manfaat pemberian probiotik untuk menurunkan kejadian EKN dan sepsis namun metode penelitian yang beragam menyulitkan penerapan hasil penelitian secara umum sehingga menimbulkan pro dan kontra penggunaan probiotik untuk BKB. ${ }^{9}$

Hasil penelitian yang dilakukan oleh Indrio, ${ }^{8}$ Samanta, ${ }^{10}$ dan Awad ${ }^{11}$ menyebutkan pemberian probiotik pada BKB dapat menurunkan kejadian EKN dan sepsis. Berbeda dengan penelitian FernandezCarrocerra, ${ }^{12}$ Braga, ${ }^{13}$ dan Sari ${ }^{14}$ yang menyebutkan tidak ada perbedaan kejadian EKN dan sepsis pada kelompok yang diberikan probiotik maupun plasebo.

Calprotectin merupakan suatu reaktan fase akut yang berperan dalam infeksi dan inflamasi. Calprotectin dapat dijadikan biomarker untuk beberapa penyakit inflamasi, termasuk inflammatory bowel disease, sepsis dan EKN. Pengukuran calprotectin feses sebagai biomarka penyakit inflamasi merupakan metode noninvasif, cepat dan mudah dilakukan. Calprotectin merupakan protein sitosol yang berikatan dengan kalsium dan seng yang terdapat dalam neutrofil granulosit. Adanya defek atau peningkatan permeabilitas barier mukosa intestinal menyebabkan terjadinya migrasi sejumlah besar granulosit ke dalam lumen intestinal sehingga calprotectin dapat ditemukan dalam feses. Pada keadaan inflamasi saluran cerna, kadar calprotectin feses akan meningkat. ${ }^{7,15,16}$

Campeotto $^{17}$ mengemukakan bahwa calprotectin feses dapat dijadikan penanda EKN stadium awal. Demikian juga penelitian yang dilakukan Mohan dan El-Frargy menyebutkan hal yang sama, terlebih pada penelitian ini menyebutkan terjadi penurunan kadar calprotectin feses pada bayi yang diberi suplementasi probiotik. $^{18,19}$

Berdasarkan latar belakang tersebut, penelitian ini bertujuan untuk mengetahui pengaruh Lactobacillus reuteri DSM 17938 terhadap kadar calprotectin feses pada BKB.

\section{Metode}

Penelitian eksperimental acak terkontrol dilakukan pada BKB yang lahir dan dirawat di Rumah Sakit Dr. Hasan Sadikin Bandung selama bulan Maret sampai Juni 2018. Lembar persetujuan (informed consent) ditandatangani oleh orangtua setelah mendapatkan penjelasan serta menyetujui bayinya ikut dalam penelitian. Kriteria inklusi adalah BKB dengan usia gestasi 30-36 minggu menurut New Ballard Score, berat badan 1000-1800 gram, dan bayi dengan hemodinamik stabil dan tidak ada gangguan absorbsi minum. Kriteria eksklusi adalah BKB dengan kelainan kongenital pada saluran cerna seperti gastroskizis, omfalokel, hernia diafragmatika, jika mengalami sepsis berat serta jika tidak didapatkan feses dalam kurun waktu 2 hari sejak lahir. Alokasi subjek ke dalam perlakuan baik kelompok probiotik maupun nonprobiotik dilakukan secara randomisasi.

Terhadap subjek dilakukan pemeriksaan kadar calprotectin feses awal kemudian diberikan perlakuan selama 2 minggu dengan menggunakan probiotik atau plasebo. Pada akhir perlakuan diperiksakan kembali kadar calprotectin feses untuk diperbandingkan. Probiotik yang diberikan adalah galur Lactobacillus 
reuteri DSM 17938 sebanyak 100 juta kuman, sedangkan untuk plasebo diberikan larutan aquabidestilata. Produk probiotik yang digunakan adalah Interlac ${ }^{\odot}$, diproduksi oleh PT. Interbat. Plasebo dimasukkan ke dalam botol yang sama bentuknya dengan Interlac ${ }^{\oplus}$. Pada bagian luar kedua botol kemasan probiotik maupun plasebo ditutup oleh label dan diberikan nomor. Penentuan pengambilan nomor botol perlakuan dilakukan secara random. Pada akhir perlakuan label tersebut dibuka.

Selama pengamatan 2 minggu dilakukan kontrol pada setiap minggu untuk mengetahui keteraturan perlakuan dan mengevaluasi kondisi klinis subjek dalam kondisi tidak mengalami perburukan. Subjek akan di-dropout apabila data tidak lengkap.

Luaran setelah perlakuan dinilai menggunakan skor sepsis modifikasi Tollner yang terdiri atas penilaian klinis dan laboratorium. Kondisi klinis yang dinilai meliputi perubahan warna kulit, mikrosirkulasi (capillary refill memanjang $>2$ detik), hipotonia muskular, bradikardia (denyut jantung $<100$ kali per menit) atau takikardia (denyut jantung $>180$ kali per menit), serangan apnea (lebih dari 20 detik), distres pernapasan (takipnea $>60$ kali per menit), pembesaran hati ( $>2 \mathrm{~cm}$ dari bawah arcus costarum), dan munculnya gejala gastrointestinal (residu lambung meningkat, muntah, distensi abdomen, dan diare). Parameter laboratorium dinilai, antara lain, $C$-reactive protein (CRP) kuantitatif serum ( $>6 \mathrm{mg} / \mathrm{L}$ ), jumlah leukosit (leukositosis $>10.000 / \mathrm{mm}^{3}$ atau leukopenia $<4000 /$ $\mathrm{mm}^{3}$ ), pada hitung jenis terdapat peningkatan jumlah neutrofil batang $\geq 20 \%$ atau ditemukan sel muda 'myelo' atau seri eritopoesis, dan trombositopenia (jumlah trombosit $<100.000 / \mathrm{mm}^{3}$ ). Interprestasi skor modifikasi Tollner adalah skor $0-4,5$ bukan sepsis, skor 5-10 tersangka infeksi, skor $>10$ mengarah ke sepsis. ${ }^{2}$

Setelah seluruh sampel feses terkumpul dari semua subjek (sebelum dan sesudah perlakuan), diperiksakan kadar calprotectin menggunakan metode enzymedlinked immunosorbent assay (ELISA) di Laboratorium Klinis RSUP dr. Hasan Sadikin Bandung Feses yang diambil sebagai sampel pemeriksaan diambil dari diapers dengan menggunakan pot khusus. Pengukuran kadar calprotectin feses ditampilkan dalam $\mu \mathrm{g} / \mathrm{g}$.

Data yang diambil tersebut dimasukkan ke dalam program perangkat lunak SPSS for windows 21.0. Uji nonparametrik digunakan untuk mengetahui perbedaan kadar calprotectin feses kedua kelompok, karena kadar calprotectin berdistribusi tidak normal maka dianalisis menggunakan uji Mann-Whitney. Uji Wilcoxon Signed Rank digunakan untuk mengetahui perbedaan kadar calprotectin feses kedua kelompok sebelum dan sesudah perlakuan. Tingkat kemaknaan penelitian ini dinyatakan bila nilai $\mathrm{p}<0,05$. Penelitian ini telah mendapat persetujuan Komite Etik Penelitian Kesehatan RSHS.

\section{Hasil}

Selama kurun waktu penelitian didapatkan $252 \mathrm{BKB}$ yang lahir di RSHS. Dari 76 bayi yang memenuhi kriteria inklusi, 40 bayi diikutsertakan dalam penelitian. Selama penelitian, 4 subjek drop out dari penelitian karena 3 subjek pulang atas permintaan keluarga dan 1 mengalami sepsis berat. Pada seluruh subjek, pengambilan sampel feses sebelum perlakuan tidak dapat dikerjakan secara simultan pada hari ke-0 dikarenakan feses keluar sebelum bayi memenuhi syarat pemberian initial feeding ataupun jumlah feses yang terlalu sedikit. Pengambilan sampel feses di pada hari ke-0 dilakukan pada 15 bayi, 8 dari kelompok probiotik dan 7 dari kelompok nonprobiotik. Sembilan belas bayi lainnya diambil sampel feses di usia hari ke-1.

Pengambilan sampel feses setelah perlakuan dilakukan pada hari ke-14-18. Apabila subjek diperbolehkan pulang sebelum 2 minggu maka selanjutnya probiotik diberikan oleh keluarga di rumah dan tetap dilakukan pemantauan lewat telepon. Selanjutnya sampel feses diambil di rumah atau di poliklinik saat bayi kontrol.

Tabel 1 memperlihatkan karakteristik dasar subjek penelitian. Pada kedua kelompok tidak menunjukkan ada perbedaan dalam hal jenis kelamin, usia kehamilan, cara lahir, berat badan lahir, dan asfiksia. Tiga puluh dua subjek mendapat antibiotik sejak usia hari pertama, masing-masing 16 subjek dari setiap kelompok $(\mathrm{p}=1,000)$. Keseluruhan subjek mendapatkan susu formula sebagai initial feeding.

Tabel 2 menunjukkan tidak ada perbedaan bermakna kadar calprotectin feses sebelum perlakuan pada kelompok probiotik dan nonprobiotik. Sementara setelah perlakuan menunjukkan terdapat perbedaan yang sangat bermakna. Penurunan kadar calprotectin pada kelompok yang diberi probiotik lebih besar dibandingkan dengan kelompok nonprobiotik. 
Tisa Rahmawaty Savitri dkk: Pengaruh Lactobacillus reuteri DSM 17938 terhadap kadar calprotectin feses sebagai penanda inflamasi intestinal pada BKB

Tabel 1. Karakteristik dasar subjek penelitian

\begin{tabular}{lcc}
\hline Karakteristik & \multicolumn{2}{c}{ Kelompok } \\
\cline { 2 - 3 } & Probiotik $(\mathrm{n}=18)$ & Nonprobiotik $(\mathrm{n}=18)$ \\
\hline Jenis kelamin & 11 & 10 \\
$\quad$ Laki-laki & 7 & 8 \\
$\quad$ Perempuan & 32,7 & 32,2 \\
Usia kehamilan (minggu) & $30-35$ & $30-35$ \\
$\quad$ Rata-rata & & 0 \\
$\quad$ Rentang & 3 & 18 \\
Cara lahir & 15 & 1455,6 \\
$\quad$ Spontan & 1411,1 & $1050-1750$ \\
$\quad$ Seksio sesarea & $1000-1700$ & 2 \\
Berat badan lahir (gram) & & 16 \\
$\quad$ Rata-rata & 15 & 16 \\
$\quad$ Rentang & 3 & 2 \\
Asfiksia & & \\
$\quad$ Ya & 16 & \\
Tidak & 2 & \\
Pemberian antibiotik & & \\
$\quad$ Ya & & \\
Tidak & & \\
\hline
\end{tabular}

Tabel 2. Pengaruh pemberian probiotik terhadap kadar calprotectin feses

\begin{tabular}{lccc}
\hline \multirow{2}{*}{$\begin{array}{l}\text { Kadar calprotectin feses } \\
(\mu \mathrm{g} / \mathrm{g})\end{array}$} & \multicolumn{2}{c}{ Kelompok } & \multirow{2}{*}{ Nilai $\left.\mathrm{p}^{*}\right)$} \\
\cline { 2 - 3 } Sebelum perlakuan & $(\mathrm{n}=18)$ & $\begin{array}{c}\text { Non probiotik } \\
(\mathrm{n}=18)\end{array}$ & \\
$\quad$ Rata-rata (SD) & $543,6(414,9)$ & $547,8(431,8)$ & 0,888 \\
$\quad$ Median & 376,6 & 412,2 & \\
$\quad$ Rentang & $104,4-1140,9$ & $106,1-1350,9$ & \\
Sesudah perlakuan & & & \\
$\quad$ Rata-rata (SD) & $30,7(44,1)$ & $254,0(289,9)$ & \\
$\quad$ Median & 19,7 & 154,6 & $<0,001$ \\
$\quad$ Rentang & $1,2-177,5$ & $77,0-1140,0$ & \\
\hline Perbandingan sebelum vs sesudah perlakuan & $\left.\mathrm{p}<0,001^{* *}\right)$ & $\left.\mathrm{p}<0,001^{* *}\right)$ & $<0,001$ \\
\hline Persentase penurunan kadar calprotectin (median) & $95,8 \%$ & $44,0 \%$ & \\
\hline
\end{tabular}

Keterangan: *) Analisis menggunakan Uji Mann-Whitney, bermakna bila nilai $\mathrm{p}<0,05$

**) Analisis menggunakan Uji Wilcoxon, bermakna bila nilai $\mathrm{p}<0,05$

Selama penelitian dilakukan pemantauan klinis setiap hari untuk memonitor efek samping gastrointestinal yang mungkin terjadi, seperti diare, konstipasi, perut kembung, retensi cairan lambung, muntah serta tanda, dan gejala sepsis. Pemeriksaan darah lengkap, kadar CRP, glukosa darah dilakukan pada usia 0 hari. Hipoglikemia simptomatis ditemukan pada 2 bayi, masing-masing 1 bayi di antara kedua kelompok, tetapi membaik dengan pemberian infus cairan D10\%. Tiga bayi dari kelompok nonprobiotik mengalami diare.
Retensi cairan lambung pada kelompok probiotik lebih sedikit terjadi (5 vs 9 bayi).

Setelah mendapat perlakuan selama 2 minggu, penilaian luaran subjek menggunakan skor sepsis modifikasi Tollner, terdiri atas penilaian klinis dan laboratorium tertera pada Tabel 3. Tidak terdapat perbedaan luaran yang bermakna antara kedua kelompok dalam hal jumlah leukosit, jumlah trombosit, dan kadar CRP ( $>00,05)$. Perbedaan yang bermakna dalam skor modifikasi Tollner pada 
Tisa Rahmawaty Savitri dkk: Pengaruh Lactobacillus reuteri DSM 17938 terhadap kadar calprotectin feses sebagai penanda inflamasi intestinal pada $\mathrm{BKB}$

Tabel 3. Perbandingan luaran

\begin{tabular}{lccc}
\hline & \multicolumn{2}{c}{ Kelompok } & \multirow{2}{*}{ Nilai p* } \\
\cline { 2 - 3 } Luaran & $\begin{array}{c}\text { Probiotik } \\
\text { Median (rentang) } \\
(\mathrm{n}=18)\end{array}$ & $\begin{array}{c}\text { Nonprobiotik } \\
\text { Median (rentang) } \\
(\mathrm{n}=18)\end{array}$ & \\
\hline Jumlah Leukosit $\left(/ \mathrm{mm}^{3}\right)$ & 14.665 & 16.960 & 0,143 \\
& $(4.060-17.360)$ & $(4.990-30.250)$ & \\
Jumlah Trombosit $\left(/ \mathrm{mm}^{3}\right)$ & 228.000 & 246.500 & 0,743 \\
CRP $(\mathrm{mg} / \mathrm{dl})$ & $(142.000-367.000)$ & $(67.000-860.000)$ & \\
Skor Tollner & $0,2(0-2,8)$ & $1,29(0-4,31)$ & 0,068 \\
\hline
\end{tabular}

Keterangan: *) uji Mann-Whitney, bermakna bila nilai $\mathrm{p}<0,05$

kelompok probiotik dan nonprobotik $(\mathrm{p}=0,004)$. Pada kelompok nonprobiotik terdapat 1 subjek yang secara klinis mengarah ke sepsis sesuai dengan skor modifikasi Tollner dengan hasil kultur darah Enterobacter clocae.

\section{Pembahasan}

Nilai median kadar calprotectin lebih tinggi dibandingkan dengan cut-off point kadar calprotectin feses pada penelitian Campeotto. Perbedaan ini disebabkan karena Campeotto mengambil subjek yang berbeda yaitu neonatus dengan usia gestasi cukup bulan. ${ }^{17} \mathrm{Hasil}$ penelitian Kapel ${ }^{16}$ juga menyebutkan hasil yang sama, yaitu kadar calprotectin feses pada BKB lebih tinggi dibandingkan BCB. Peningkatan kadar calprotectin ini menunjukkan peningkatan permeabilitas intestinal sehingga menyebabkan migrasi neutrofil ke dalam lumen dan mukosa usus sebagai bagian dari proses pembentukan gut-associated lymphoid tissue (GALT) sehingga calprotectin ditemukan dalam feses. Faktor lain yang dapat memengaruhi kadar calprotectin yang tinggi adalah pengambilan sampel feses langsung dari popok menyebabkan air diserap langsung ke dalam popok. ${ }^{15,16}$

Kadar calprotectin feses dapat dijadikan biomarka penyakit inflamasi termasuk EKN dan sepsis. Zhang ${ }^{20}$ dan El Frargy ${ }^{19}$ menyebutkan bahwa kadar calprotectin feses dapat digunakan prediktor dini EKN dan enteropati dengan cut offpoint $281 \mathrm{dan} 482 \mu \mathrm{g} / \mathrm{g}$. Pada penelitian ini nilai rerata kadar calprotectin feses lebih rendah. Hal tersebut menunjukkan bahwa subjek tidak mengalami EKN maupun enteropati.

Terdapat penurunan kadar calprotectin feses, baik pada kelompok probiotik maupun nonprobiotik. Hal ini sesuai dengan perjalanan alamiahnya bahwa kadar calprotectin feses akan menurun sejalan dengan bertambahnya umur. ${ }^{15}$ Persentase penurunan kadar calprotectin feses pada kelompok probiotik lebih besar dibandingkan dengan kelompok nonprobiotik dengan tingkat kemaknaan $p<0,001$. Hal tersebut sesuai dengan penelitian sebelumnya yang menyebutkan probiotik berpengaruh dalam menurunkan kadar calprotectin. ${ }^{18,19}$

Probiotik telah digunakan dalam penelitian sebelumnya dengan populasi BKB atau berat badan lahir rendah (BBLR). Pada penelitian kami, probiotik yang digunakan adalah galur Lactobacillus rueteri DSM 17938 selama 14 hari sedangkan El-Frargy mengggunakan kombinasi probiotik Lactobacillus acidophillus dan Bifidobacterium bifidum selama 14 hari untuk mengurangi kejadian EKN dan sepsis serta calprotectin feses dibandingkan kelompok plasebo. ${ }^{19}$ Mohan $^{18}$ melaporkan hal yang sama, yaitu pemberian Bifidobacterium lactis Bb12 selama 21 hari pada BKB dapat menurunkan kadar calprotectin feses serta kejadian EKN.

Pada penelitian Oncel ${ }^{21}$ probiotik galur Lactobacillus reuteri DSM 17938 telah diberikan pada BKB dan BBLR dengan hasil kejadian EKN tidak berbeda antara kelompok probiotik dan plasebo, tetapi pada kedua penelitian ini tidak diukur kadar calprotectin feses.

Luaran setelah perlakuan dinilai menggunakan skor sepsis modifikasi Tollner yang terdiri atas penilaian klinis dan laboratorium. Pada penelitian ini seluruh subjek pada kedua kelompok setelah perlakuan tidak mengalami sepsis dilihat dari nilai median skor modifikasi Tollner pada kedua kelompok.

Keseluruhan subjek setelah mendapat perlakuan memiliki kadar CRP $<6 \mathrm{mg} / \mathrm{L}$ sehingga tidak menunjukkan adanya inflamasi sistemik. Kadar CRP tidak dapat digunakan sebagai prediktor timbulnya EKN karena CRP juga meningkat pada keadaan 
Tisa Rahmawaty Savitri dkk: Pengaruh Lactobacillus reuteri DSM 17938 terhadap kadar calprotectin feses sebagai penanda inflamasi intestinal pada BKB

inflamasi sistemik lain sehingga CRP tidak spesifik untuk EKN. ${ }^{23}$ Meskipun demikian, kondisi ini tidak menyingkirkan kemungkinan adanya inflamasi intestinal karena tidak dilakukan perhitungan jumlah koloni dan kultur kuman intestinal.

Berbeda dengan kadar CRP, menurut penelitian sebelumnya kadar calprotectin feses telah banyak digunakan prediktor EKN. ${ }^{11,19,24}$ Pada kondisi EKN maupun sepsis terjadi inflamasi dimana neutrofil yang teraktivasi akan menginfiltrasi mukosa intestinal dan menghasilkan sitokin dan kemokin proinflamasi yang akan mengaktivasi sel-sel inflamasi termasuk makrofag ke saluran cerna. Neutrofil juga akan bermigrasi ke lumen saluran cerna pada keadaan inflamasi intestinal sehingga akan meningkatkan ekskresi calprotectin dalam feses. Dengan demikian, calprotectin feses dapat digunakan sebagai penanda inflamasi intestinal. ${ }^{7}$

Pengukuran kadar calprotectin feses sebagai penanda inflamasi intestinal merupakan metode yang non-invasif, cepat, dan mudah dilakukan. Ikatan calprotectin dengan kalsium menyebabkan protein ini tahan terhadap degradasi bakteri feses dan tetap stabil selama tujuh hari pada suhu kamar. ${ }^{17}$

Tidak terdapat korelasi penurunan persentase kadar calprotectin feses dengan luaran subjek setelah perlakuan. C-reactive protein, reaktan fase akut yang akan meningkat pada keadaan inflamasi sistemik, sebagai luaran berkorelasi negatif dengan penurunan kadar calprotectin, dengan nilai statistik yang tidak bermakna. Ini menunjukkan bahwa inflamasi sistemik tidak memengaruhi kadar calprotectin feses apabila tidak didapatkan manifestasi klinis abdominal, sesuai dengan teori yang menyebutkan bahwa calprotectin dapat ditemukan dalam feses apabila terdapat kerusakan pada integritas mukosa intestinal. ${ }^{24}$

Keterbatasan penelitian ini adalah tidak dilakukan perhitungan jumlah koloni kuman intestinal sehingga belum dapat disingkirkan subjek tidak mengalami infeksi saluran cerna. Selain itu, penelitian ini tidak dilakukan konfirmasi diagnosis EKN sehingga belum dapat disingkirkan subjek tidak mengalami EKN. Penelitian uji klnis lain yang lebih lengkap masih diperlukan untuk menyempurnakan hasil yang didapatkan.

\section{Kesimpulan}

Pemberian probiotik Lactobacillus reuteri DSM 17938 pada BKB dapat menurunkan kadar calprotectin feses.
Dengan demikian diharapkan dapat menjadi bahan referensi tentang perlunya pemberian probiotik pada $\mathrm{BKB}$ untuk mencegah terjadinya inflamasi intestinal.

\section{Daftar pustaka}

1. Goldenberg RL, Culhane JF, Iams JD, Romero R. Preterm birth 1: epidemiology and causes of preterm birth. Obstet Anesth Dig [Internet] 2009;29:6-7.

2. Gerdes JS. Diagnosis and management of bacterial infections in the neonate. Pediatr Clin North Am 2004;51:939-59.

3. Patel BK, Shah JS. Necrotizing enterocolitis in very low birth weight Infants: a systemic review. ISRN Gastroenterol [Internet] 2012;2012:1-7.

4. Lee JH. An update on necrotizing enterocolitis: Pathogenesis and preventive strategies. Korean J Pediatr 2011;54:368-72.

5. Yuniati T. Peningkatan berat badan bayi baru lahir dengan seksio sesarea yang diberikan kombinasi asi dengan susu formula mengandung probiotik dan nonprobiotik. Sari Pediatri 2012;14:251-5.

6. Sarkar S, Sur A, Das K, J.Boral. Safety of probiotics for preterm infants - a review. Nutr Food Toxicol 2017;1:219-27.

7. Leach ST, Day AS. S100 proteins in the pathogenesis and diagnosis of inflammatory bowel disease. Expert Rev Clin Immunol 2006;2:471-80.

8. Indrio F, Riezzo G, Raimondi F, Bisceglia M, Cavallo L, Francavilla R. The effects of probiotics on feeding tolerance, bowel habits, and gastrointestinal motility in preterm newborns. J Pediatr 2008;152:801-6.

9. Ofek Shlomai N, Deshpande G, Rao S, Patole S. Probiotics for preterm neonates: what will it take to change clinical practice? Neonatology 2013;105:64-70.

10. Samanta M, Sarkar M, Ghosh P, Ghosh JK, Sinha MK, Chatterjee S. Prophylactic probiotics for prevention of necrotizing enterocolitis in very low birth weight newborns. J Trop Pediatr 2009;55:128-31.

11. Awad h, Mokhtar H, Imam SS, Gad GI, Havez H, Aboushady $\mathrm{N}$. Comparison between killed and living probiotic usage versus placebo for the prevention of necrotizing enterocolitis and sepsis in neonates. Pakistan J Biol Sci 2010;13:253-62.

12. Fernández-Carrocera LA, Solis-Herrera A, Cabanillas-Ayón M, Gallardo-Sarmiento RB, García-Pérez CS, MontañoRodríguez R, dkk. Double-blind, randomised clinical assay to evaluate the efficacy of probiotics in preterm newborns weighing less than $1500 \mathrm{~g}$ in the prevention of necrotising enterocolitis. Arch Dis Child Fetal Neonatal Ed 2013;98:F5-9.

13. Braga TD, Alves G, Israel P, Lira C De, Lima MDC. Efficacy of bifidobacterium breve and lactobacillus casei oral 
Tisa Rahmawaty Savitri dkk: Pengaruh Lactobacillus reuteri DSM 17938 terhadap kadar calprotectin feses sebagai penanda inflamasi intestinal pada BKB

supplementation on necrotizing enterocolitis in very-lowbirth-weight preterm infants : a double-blind, randomized, controlled trial 1-3. J Clin 2011;81-6.

14. Sari FN, Dizdar EA, Oguz S, Erdeve O, Uras N, Dilmen U. Oral probiotics: lactobacillus sporogenes for prevention of necrotizing enterocolitis in very low-birth weight infants: a randomized, controlled trial. Eur J Clin Nutr [Internet] 2011;65:434-9.

15. Savino F, Castagno E, Calabrese R, Viola S, Oggero R, Miniero R. High faecal calprotectin levels in healthy, exclusively breastfed infants. Neonatology 2010;97:299-304.

16. Kapel N, Campeotto F, Kalach N, Baldassare M, Butel MJ, Dupont C. Faecal calprotectin in term and preterm neonates. J Pediatr Gastroenterol Nutr 2010;51:542-7.

17. Campeotto F, Butel MJ, Kalach N, Derrieux S, Aubert-Jacquin C, Barbot L, dkk. High faecal calprotectin concentrations in newborn infants. Arch Dis Child Fetal Neonatal Ed 2004;89:353-6.

18. Mohan R, Koebnick C, Schildt J, Mueller M, Radke M, Blaut M. Effects of bifidobacterium lactis bb12 supplementation on body weight, fecal ph, acetate, lactate, calprotectin, and igA in preterm infants. Pediatr Res 2008;64:418-22.
19. El-frargy MS, Hassan AM. The effect of probiotics supplementation on fecal calprotectin as an early marker of neonatal enteropathy. J Am Sci 2014;10:209-13.

20. Zhang NM, Zhang X, Zhang J. Diagnostic value of fecal calprotectin in preterm infants with necrotizing enterocolitis. Clin Lab. 2016;62:863-9.

21. Oncel MY, Sari FN, Arayici S, Guzoglu N, Erdeve O, Uras $\mathrm{N}$, dkk. Lactobacillus reuteri for the prevention of necrotising enterocolitis in very low birthweight infants: a randomised controlled trial. Arch Dis Child Fetal Neonatal Ed 2014;99:110-6.

22. Shadkam MN, Jalalizadeh F, Nasiriani K. Effects of probiotic lactobacillus reuteri (DSM 17938) on the incidence of necrotizing enterocolitis in very low birth weight premature infants. Iran J Neonatol 2015;6:15-20.

23. Fox TP, Godavitarne C. What really causes necrotising enterocolitis? ISRN Gastroenterol 2012;2012:628317.

24. Aydemir O, Aydemir C, Sarikabadayi YU, Emre Canpolat F, Erdeve O, Biyikli Z, dkk. Fecal calprotectin levels are increased in infants with necrotizing enterocolitis. J Matern Neonatal Med 2012;25:2237-41. 